4 Savvas a Hieromonk of the Holy Mountain. Passions and depression. What they are and how they are treated. Kerasia: Holy Cell "The Presentation of the Mother of God"; 2012. p. 51-8. Greek.

5 Larchet J-C. Therapy of spiritual illnesses: an introduction to the ascetic tradition of the orthodox church Athens: Apostoliki Diakonia of the Church of Greece; 2011. v. 1, p.243-55.

6 Saint John Climacus. Ladder of divine ascent (Greek: K $\lambda \hat{i} \mu \alpha \xi$; Latin: Scala Paradisi), Speech 14th. Patrologia Graeca (PG). 1864; 88:864-72.

7 Mazokopakis EE. The prevention of cholera in the Bible. Vaccine. 2019;37:4850.

\section{Burnout in psychiatry residents: the role of relations with peers, preceptors, and the institution}

Braz J Psychiatry. 2020 Mar-Apr;42(2):226-227 doi:10.1590/1516-4446-2019-0797

(cc) BY-NC

Physicians have a higher prevalence of mental health problems compared to the general population. The prevalence of burnout in residents has been reported to range between 25 and $75 \%$, and burnout has been associated with increased medical errors, suboptimal care of patients, and reduced empathy. ${ }^{1,2}$ Despite current knowledge about the problem and several interventions implemented to date, rates are still rising, with some authors now talking of a burnout epidemic. ${ }^{3}$

The aim of this cross-sectional study was to evaluate the association between burnout and perceived relations with preceptors, peers, and the institution. Approval was obtained from the local ethics committee (protocol 70231 617.6.0000.5327). All psychiatry residents from a city in the South of Brazil were invited $(n=87)$, and $66(76 \%)$ agreed to participate. A sociodemographic questionnaire was administered, burnout symptoms were evaluated by means of the Maslach Burnout Inventory (MBI), and relations by means of the Work Environment Evaluation Instrument (WEEI). 4

The mean age of the participants was $28.3 \pm 3.1$ years, and $53 \%$ were male. According to the cutoff point most frequently used in the literature, 55 participants $(83.3 \%)$ would be classified as meeting the burnout criteria: $47 \%$ were positive for emotional exhaustion (EE), 62.1\% for depersonalization (DP), and 69.7\% for personal accomplishment (PA). Relations with preceptors, the institution, and peers all correlated with EE and DP (Table 1). The items most correlated with EE were "I feel that I am always short of what the preceptors expect of me" $\left(r_{\mathrm{s}}=\right.$ 0.53; $p<0.001)$, "I feel more pressured than helped by my preceptors" $\left(r_{s}=0.43 ; p<0.001\right)$, and "I feel a collaborative climate in my institution" $\left(r_{s}=-0.39\right.$; $p=0.001)$. DP correlated more with the items "I feel a collaborative climate in my institution" $\left(r_{s}=-0.47 ; p<\right.$ $0.001)$, "I feel like I belong to my institution" $\left(r_{s}=-0.46\right.$; $p<0.001$ ), and "I feel more pressured than helped by my preceptors" ( $\left.r_{s}=0.43 ; p<0.001\right)$. PA correlated with the relationship with peers and the institution (Table 1). The items most correlated with PA were "I feel like I belong to my institution" $\left(r_{s}=0.33 ; p=\right.$ $0.007)$, "I feel a collaborative climate in my institution" $\left(r_{s}=0.32 ; p=0.008\right)$, and "My colleagues are not my friends" ( $\left.r_{s}=-0.28 ; p=0.024\right)$.

These findings highlight potentially modifiable institutional factors as a way to face the rising rates of burnout among health professionals and emphasize the need for further investigations on the subject. Interventions aimed at improving the quality of relations within institutions may have great potential for reducing burnout rates and mental health problems in physicians and other health professionals, as well as improving their well-being.

Gabriela M. Carneiro Monteiro, iD Ives C. Passos, Fernanda L.C. Baeza, Simone Hauck iD Programa de Pós-Graduação em Psiquiatria e Ciências do Comportamento, Universidade Federal do Rio Grande do Sul (UFRGS), Porto Alegre, RS, Brazil.

Submitted Nov 24 2019, accepted Dec 212019.

\section{Disclosure}

The authors report no conflicts of interest.

How to cite this article: Carneiro Monteiro GM, Passos IC, Baeza FLC, Hauck S. Burnout in psychiatry residents: the role of relations with peers, preceptors, and the institution. Braz J Psychiatry. 2020;42:226-227. http://dx.doi. org/10.1590/1516-4446-2019-0797

Table 1 Correlations (Spearman's rho) between WEEl and burnout dimensions

\begin{tabular}{|c|c|c|c|}
\hline & WEEI peers & WEEI preceptors & WEEl institution \\
\hline Emotional exhaustion total & $0.337^{*}$ & $0.558 *$ & $-0.428 *$ \\
\hline Depersonalization total & $0.327 *$ & $0.481 *$ & $-0.457^{*}$ \\
\hline Personal accomplishment total & $-0.280^{\dagger}$ & -0.180 & $0.351 *$ \\
\hline
\end{tabular}

WEEI = Work Environment Evaluation Instrument.

* Significant at $p<0.01$.

$\dagger$ Significant at $p<0.05$. 


\section{References}

1 West CP, Huschka MM, Novotny PJ, Sloan JA, Kolars JC, Habermann $\mathrm{TM}$, et al. Association of perceived medical errors with resident distress and empathy: a prospective longitudinal study. JAMA. 2006;296: 1071-8.

2 Shanafelt TD, Bradley KA, Wipf JE, Back AL. Burnout and selfreported patient care in an internal medicine residency program. Ann Intern Med. 2002;136:358-67.
3 Hauck S, Gabbard GO. Institutional factors in the medical burnout epidemic. Braz J Psychiatry. 2019;41:191-2.

4 Schaufeli WB, Leiter MP, Maslach C, Jackson SE. Maslach Burnout Inventory - General Survey. In:Maslach C, Jackson SE, Leiter MP. The Maslach Burnout Inventory: test manual 3rd ed. Palo Alto: Consulting Psycologist Press; 1996. p.19-26.

5 Carneiro Monteiro GM, Baeza FLC, Hauck S. Work Environment Evaluation Instrument (WEEI): development, validation and association with burnout. Trends Psychiatry Psychother. Forthcoming 2020. 